\title{
Description of a sauropod dinosaur braincase (Titanosauridae) from the Late Cretaceous Rio Colorado Subgroup, Patagonia
}

\author{
JORGE O. CALVO ${ }^{1}$ and ALEXANDER W. KELLNER ${ }^{2}$ \\ ${ }^{1}$ Centro Paleontológico Lago Barreales, Universidad Nacional del Comahue \\ Ruta Pro. 51 km 65, Buenos Aires 1400, 8300 Neuquén, Argentina \\ ${ }^{2}$ Museu Nacional/UFRJ, São Cristóvão, Quinta da Boa Vista s/n \\ 20940-040 Rio de Janeiro, RJ, Brasil
}

Manuscript received on March 29, 2005; accepted for publication on September 12, 2005; contributed by ALEXANDER W. KELLNER*

\begin{abstract}
The fossil record of cranial material from titanosaurid sauropods is very poor and no complete skull has been described so far. Here we describe a new braincase (MUCPv-334) that was recovered from reddish sandstones of the Rio Colorado Subgroup (Late Cretaceous) of the region of Bajo del Añelo, approximately 20 km north of the town Añelo (Neuquén Province, Argentina). This specimen is attributed to the Titanosauridae based on the ventrally projected basipterygoid processes, a common condition shared by other titanosaurids. The robustness of MUCPv-334 together with an unusually expanded crista prootica and the presence of an anterior prolongation of the parasphenoid reaching the basal tubera were not reported in other members of the Titanosauridae, indicating a larger diversity in the braincase morphology of this sauropod clade than previously thought.
\end{abstract}

Key words: braincase, Titanosauridae, Late Cretaceous, Patagonia, Argentina.

\section{INTRODUCTION}

The fossil record of cranial material belonging to the Titanosauria (sensu Salgado et al. 1997) is very poor. The best specimens are those of Antarctosaurus wichmannianus Huene 1929 (Huene 1929), Saltasaurus loricatus Bonaparte and Powell 1980 (Powell 1992), Rapetosaurus krausei Rogers and Forster 2001 (Rogers and Forster 2001, 2004) and Nemegtosaurus mongoliensis Nowinski 1971 (Nowinski 1971), the later considered closely related to the Titanosauridae (Salgado and Calvo 1997). There are also descriptions of some fragmentary cranial material belonging to Malawisaurus dixeyi

*Member, Academia Brasileira de Ciências

Correspondence to: A.W.A. Kellner

E-mail: kellner@mn.ufrj.br
(Haughton 1928) (Jacobs et al. 1993), Antarctosaurus septentrionalis Huene and Matley 1933 (Huene and Matley 1933, Chatterjee and Rudra 1996), Titanosaurus indicus Lyedekker 1877 (Chatterjee and Rudra 1996), Ampelosaurus atachis Le Loeuff 1995 (Le Loeuff et al. 1989), and Quaesitosaurus orientalis Kurzanov and Bannikov 1983 (Kurzanov and Bannikov 1983), the later also regarded as closely related to the Titanosauridae (Salgado and Calvo 1997). Besides those there are unnamed titanosaurids from India (Berman and Jain 1982), Rumania (Weishampel et al. 1991), Texas (Tidwell and Carpenter 2003), Uzbekistan (H.D. Sues, pers. com.) and Brazil, the latter composed of a jaw fragment (Henriques et al. 2002). Recently an 
almost complete titanosaurid skull was briefly mentioned form Patagonia (Calvo et al. 1997, Coria and Salgado 1998) but it still remains undescribed.

Here we report another titanosaurid braincase housed in the paleovertebrate collections of the Museo de Geología y Paleontología de la Universidad Nacional del Comahue (MUCPv). The specimen (MUCPv-334; cast at the Museu Nacional/ UFRJ - MN 6913-V) was discovered in December 1999 by the technician Federico Poblete during a fieldtrip to Bajo del Añelo, Neuquén Province, Argentina. It was found $20 \mathrm{~km}$ north of the town of Añelo, at the southern margin of the Añelo Basin, in a reddish sandstone layer of the Rio Colorado Subgroup (Ardolino and Franchi 1996), Rio Neuquén Group (Cazau and Uliana 1973, Leanza and Hugo 2001). No detailed stratigraphic column of this site is known. Two articulated titanosaurid tails were collected about 200 meters away from this specimen, but it is not possible at the time being to relate this braincase to one of those caudal vertebral series. More titanosaurid material related to those caudals remains in the field.

This specimen (MUCPv-334) shows some interesting anatomical features and is compared with other sauropod cranial material, increasing the diversity of the braincase morphology within the Titanosauridae. It was briefly reported before (Calvo and Kellner 2004) and is fully described here.

\section{DESCRIPTION AND COMPARISONS}

The sauropod braincase (MUCPv-334) described here is incomplete and shows only the occipital region. It consists of the following elements: supraoccipital, both exoccipital-opisthotics, part of the paroccipital processes, the basioccipital neck, basisphenoid, incomplete parasphenoid, both prootics, right laterosphenoid and the posterior part of the right orbitosphenoid (Figs. 1-4). The braincase measures $140 \mathrm{~mm}$ from the supraoccipial apex to the preserved distal end of the basipterygoid process, and has a width (between the paroccipital processes) of $120 \mathrm{~mm}$. The preservation of the bone surface is good and except for the laterosphenoid-orbitosphenoid, which is displaced lateroventrally from its original anatomical position, there is almost no distortion. Most of the bones that form the braincase are fused or tightly connected, a common condition in sauropod braincases.
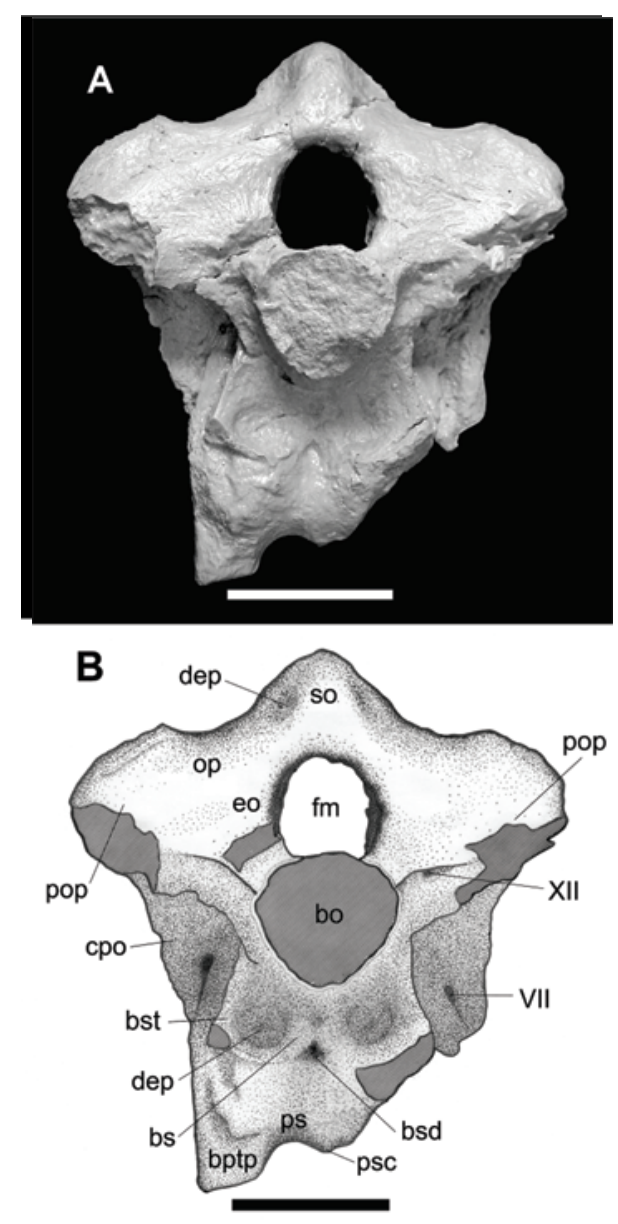

Fig. 1 - Occipital view of the titanosaurid braincase from the Rio Colorado Subgroup. A) Photo of the cast (MN 6913-V); B) Drawing. Abbreviations: bo: basioccipital; bptp: basipterygoid process; bs: basisphenoid; bsd: basisphenoidal depression; bst: basisphenoidal tuber; cao: crista antotica; cpo: crista prootica; dep: depression; eo: exoccipital; fov: fenestra ovalis; fo: foramen; fm: foramen magnum; ls: laterosphenoid; op: opisthotic; os: orbitosphenoid; ps: parasphenoid; psc: parasphenoidal crest; pop: paroccipital process; pr: prootic; so: supraoccipital; III,IV,V,VI,IX-XI: exit for cranial nerves. Scale bar $=$ $40 \mathrm{~mm}$. 

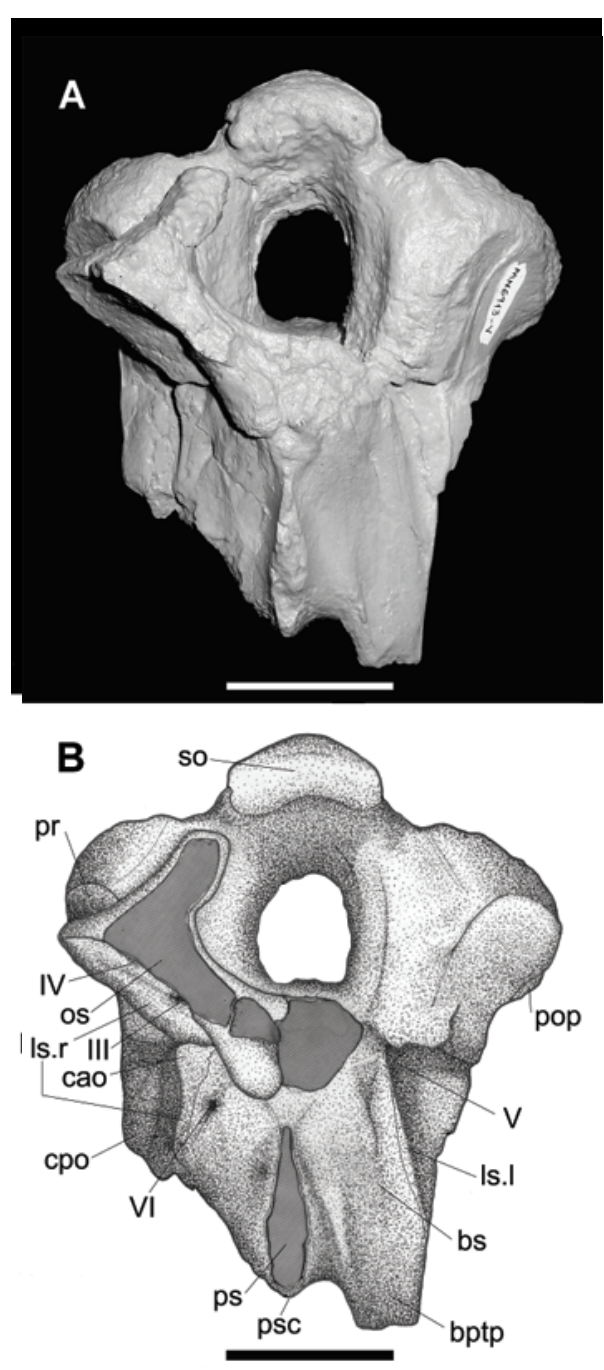

Fig. 2 - Anterior view of the titanosaurid braincase from the Rio Colorado Subgroup. A) Photo of the cast (MN 6913-V); B) Drawing. Abbreviations as in figure 1. Scale bar $=40 \mathrm{~mm}$.

The foramen magnum is suboval with its longest axis directed dorsoventrally $(30 \mathrm{~mm}$ high $\times$ $26 \mathrm{~mm}$ width). Based on the preserved portion of the basioccipital neck, it is likely smaller than the occipital condyle (not preserved). No evidence of the posttemporal fenestra is observed.

As in most titanosaurid braincases, the supraoccipital of MUCPv-334 is apparently fused with the exoccipital, and its shape is difficult to be determined. There are two symmetrical breaks directed dorsoventrally, but it is not clear if they actually
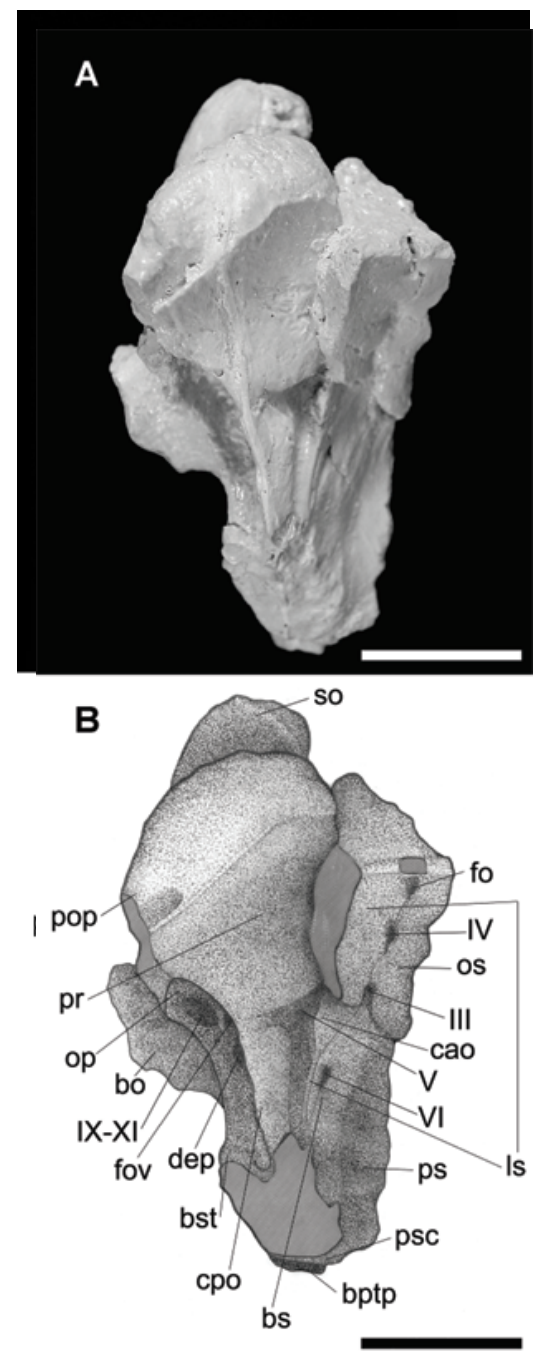

Fig. 3 - Right lateral view of the titanosaurid braincase from the Rio Colorado Subgroup. A) Photo of the cast (MN 6913-V); B) Drawing. Abbreviations as in figure 1. Scale bar $=40 \mathrm{~mm}$.

indicate the limits of this bone. In any case, the supraoccipital is a robust element that forms the dorsal margin of the foramen magnum. At the midline it forms a transversely convex prominence that rises anterodorsally, reaching the dorsal plane of the skull and connecting with the parietals (not preserved). On either side of this prominence the supraoccipital levels out laterally and meets the exoccipital, forming an expanded and dorsally concave shelf. A shallow depression is present on the lateral side 

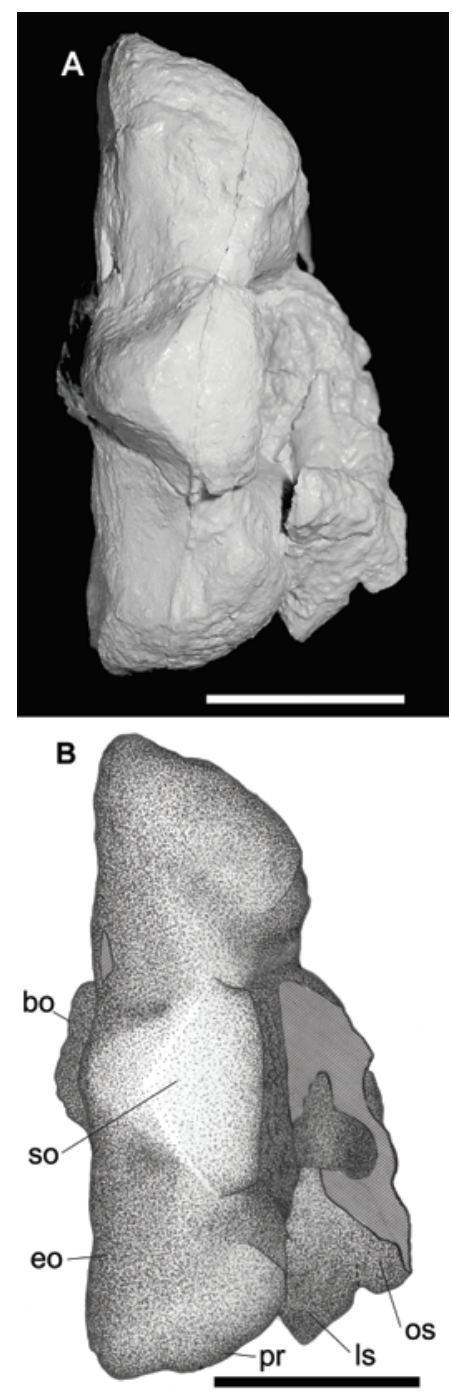

Fig. 4 - Dorsal view of the titanosaurid braincase from the Rio Colorado Subgroup. A) Photo of the cast (MN 6913-V); B) Drawing. Abbreviations as in figure 1. Scale bar $=40 \mathrm{~mm}$.

of the prominence. This prominence in MUCPV334 is broader than in Antarctosaurus septentrionalis that also has deeper lateral depressions (Chatterjee and Rudra 1996, Fig. 11A). The latter has two distinct lateral depressions that are shallower in MUCPv-334. In MUCPv-334, the anterodorsal surface that contacts the parietals is convex and has an elongated triangular outline (Fig. 2). The supraoccipital of MUCPV-334 also differs from Saltasaurus
(Powell 2003), Rapetosaurus (Rogers and Forster 2001), and Quaestitosaurus (Kurzanov and Bannikov 1983) by lacking a longitudinal groove (or midline depression) that coincides with the sagittal plane. MUCPv-334 differs with Rapetosaurus (Rogers and Forster 2001), Antarctosaurus wichmannianus (Huene 1929), Antarctosaurus septentrionalis (Huene and Matley 1933), Nemegtosaurus (Nowinsky 1971) and TMM 40435 (Tidwell and Carpenter 2003) in the absence of a clearly delimited nuchal crest.

The exoccipital participates in the dorsolateral rim and probably also in the lateral margin of the occipital condyle as in Antarctosaurus wichmannianus (Huene 1929). Therefore, this cranial element probably bounds completely the lateral walls of the foramen magnum and the floor of the neural channel in the condylar neck. Two protuberances occur on both sides of the foramen magnum as in the titanosaurid Saltasaurus and the diplodocid Amargasaurus (Salgado and Bonaparte 1991), but they are smoother and less developed in MUCPv334. The surface of those protuberances is striated, suggesting that they were used for muscle attachment likely related with the neck musculature. The exoccipital expands dorsally and forms a wide contact for the parietal $(18 \mathrm{~mm})$. Laterally it expands and fuses with the opisthotic and, in posterior view, those elements cannot be individualized. The exoccipital-opisthotic further fuse with the paroccipital process. Near the lower rim of the foramen magnum, each exoccipital is pierced by a foramen for cranial nerve XII (N. Hypoglossus), as observed in "Antarctosaurus" septentrionalis (Chatterjee and Rudra 1996, Fig. 11A).

The paroccipital processes are incomplete and lack the distal ends. Nevertheless the preserved section indicates that they were deflected as in Saltasaurus (Powel 1992) and Antarctosaurus. Although the dorsal limits are not clear due to fusion with the exoccipital-opisthotic, the top of the paroccipital process is level with the foramen magnum. From the preserved portion of those elements in MUCPv334 , the paroccipital processes lack a posterodorsal 
notch present in Rapetosaurus, Quaesitosaurus, and Jainosaurus reported by Rogers and Forster (2004).

The occipital condyle is missing and only the condylar neck is preserved (Figs. 1, 3). It is clear from the preserved portion that the occipital condyle is posteroventrally directed, as in most Titanosauromorpha (Salgado et al. 1997) and largely formed by the basioccipital. The sutures of the basioccipital and the surrounding elements are not visible.

The basisphenoid is completely fused with the parasphenoid. On each side it forms a small and poorly developed basal tuber and the basipterygoid process. The basal tuber and basipterygoid process are fused and participate in the anterior half of the crista prootica. Furthermore, the basal tubera are fused in the midline as in Saltasaurus, but can be differentiated in two distinct areas on the ventral side. The area closest to the occipital condyle shows a depression surrounded by a sharp ridge as in Antarctosaurus wichmannianus (Fig. 1). The distal parts of the tubera form a bony mass from which the basipterygoid processes arise (as in Saltasaurus). The basal tuber is similar to that of Saltasurus in its massiveness but each tuber is more elaborated in MUCPv-334. Between them there is a shallow basisphenoidal depression (Fig. 1).

The basipterygoid processes are not complete. They diverge from each other at an angle of less than 30 degrees relative to the midline. The preserved portion of the left basipterygoid process indicates that this element was stout and short. On the anterolateral part, close to the contact with the laterosphenoid, there is a foramen for the exit of cranial nerve VI (Fig. 2).

In anterior view, the parasphenoid (not well preserved dorsally) is long, robust, and directed anteroposteriorly. It expands anteriorly and curves ventro-posteriorly reaching the basal tubera as a crest. So far a parasphenoidal crest between the two basipterygoid processes has not been reported in any other titanosaurid skull.

The opisthotic is fused with the exoccipital and can only be distinguished in ventrolateral view (Fig. 3). This bone is hidden by the prootic. The prootic-opisthotic suture is partially preserved as a faint and almost straight line. The opisthotic forms most of the dorsal margin of the fenestra ovalis, which is bordered anteriorly by the prootic and posteriorly by paroccipital process. Ventrolaterally the opisthotic is pierced by some foramina that constitute the exits of the cranial nerves IX, X, and XI.

The prootic is well developed. Although the distal ends are lacking, the preserved portion of the crista prootica indicates that it is expanded laterally, more than in any other titanosaurid braincase described so far. The lateral border is directed downward and almost parallel to the skull axis. It forms the exit of cranial nerve $\mathrm{V}$ together with the laterosphenoid. Two strong sulci are situated on the anterior face of the crista prootica and constitute the exits for the mandibular branch (placed laterally) and for the maxillary branch (placed anteriorly) of cranial nerve V. Posteriorly, the prootic is pierced by a foramen, possible the exit of the facial nerve (VII).

The laterosphenoid lies between the orbitosphenoid and the prootic. This portion of MUCPv334 is only preserved on the right side, where it is ventrolaterally displaced from its original position. Dorsally the laterosphenoid is expanded, turning into a splint-like bone ventrally (Fig. 1). The contact surface with the frontal (not preserved) is flat and elongated lateromedially. The limit between the laterosphenoid and the orbitosphenoid passes through the foramina for cranial nerves III and IV. A third foramen, whose function is unknown, is situated close to the dorsal margin. Laterally the laterosphenoid is expanded, forming the crista antotica that is directed posteroventrally, forming the anterodorsal margin of a large passage for cranial nerve $\mathrm{V}$. Based on this region of MUCPv-334, the area of Rapetosaurus krausei labeled as the laterosphenoid by Rogers and Forster $(2001,2004)$ most likely includes, besides the laterosphenoid, the orbitosphenoid and possible part of the prootic.

Only the right orbitosphenoid is partially preserved, clearly indicating that it met anteriorly with its counterpart, a common feature observed in other 
sauropod braincases. The suture with the laterosphenoid passes through the exit of cranial nerves III and IV. The portion with the exit of cranial nerve II is not preserved.

\section{DISCUSSION AND CONCLUSION}

Although incomplete, the basic structure of the braincase MUCPv-334 unequivocally allows its allocation to the Sauropoda, being very different from all other vertebrates (e.g., Romer 1956), including theropods (e.g., Currie and Zhao 1994) and pterosaurs (Kellner 1996). Based on the position of the basipterygoid processes and the occipital condyle, it is possible to determinate the orientation of the basicranium (Salgado and Calvo 1997). If the supraoccipital of MUCPv-334 is oriented vertically, the paroccipital processes project posteroventrally and the basipterygoid processes project ventrally, a condition common to other titanosaurids such as Saltasaurus (Powell 2003) and Antarctosaurus (Huene 1929). Moreover, MUCPv-334 has short and robust basipterygoid processes that are present in Camarasaurus and Titanosauridae but not in Diplodocimorpha (Calvo and Salgado 1995, Salgado 1999). Although incomplete, the preserved portion of the paroccipital processes in MUCPv-334 suggests that they are long and curved, a character commonly referred to the Titanosauridae (Salgado and Calvo 1997). Based on those features, we refer MUCPv334 to the Titanosauridae.

Two kinds of skull architecture are traditionally recognized within Sauropoda: a diplodocoid and a camarasauroid-brachiosauroid type (Janensch 1929, Romer 1956, Coombs 1975, McIntosh and Berman 1975, Powell 2003, McIntosh 1990a, b, Dodson 1990, Salgado and Bonaparte 1991). Regarding the Titanosauridae, the skull has been interpreted as corresponding to either type, some authors favoring a Diplodocus-like skull (Huene 1929, Romer 1956, Nowinski 1971, Gauthier 1986, McIntosh 1990a, b, Jacobs et al. 1993, Rogers and Foster 2001, 2004) and others favoring a more camarasaurid-brachiosaurid shape (Calvo 1994, Hunt et al.
1994, Salgado and Calvo 1997). MUCPv-334 does not provide any new evidence bearing on this controversy.

Compared to other titanosaurid braincases, MUCPv-334 has poorly developed basal tubera similar to those present in Saltasaurus, each having a marked depression, close to the occipital condyle as observed in Antarctosaurus. The angle between the basipterygoid processes in $\mathrm{MUCPv}-334$ is relatively smaller (around $30^{\circ}$ ) than in Antarctosaurus and Rapetosaurus, similar to the condition observed in more primitive sauropods. The posterodorsal margin of the skull, with a marked depression lateral to the supraoccipital of MUCPv-334 (Fig. 1), differs from the more rounded margins of Saltasaurus (Powell 2003), Rapetosaurus (Rogers and Forster 2004), and Titanosaurus (Chatterjee and Rudra 1996).

The robust basicranium together with an unusually expanded crista prootica and the presence of an anterior prolongation of the parasphenoid reaching the basal tubera are the most striking features of MUCPv-334, different from the condition in other Titanosauridae. Although those differences suggest that MUCPv-334 probably belongs to a distinct taxon, we prefer to wait until more complete material is found to better characterize this taxon. Nevertheless, comparisons of MUCPv-334 with other titanosaurid braincases indicates that the morphology of the basicranium in those sauropods shows considerable variation.

\section{ACKNOWLEDGMENTS}

We thank the technician Federico Poblete (Centro Paleontológico Lago Barreales), for his continuous efforts in colleting important vertebrate fossils from the Neuquén Province and making them available to Science; Vanessa D. Machado (Museu Nacional/ UFRJ) for the drawings of the specimen and Orlando Grillo (Museu Nacional/UFRJ) for editing the images. This project was partially funded by grants to J.O.C. from the National University of Comahue (Project T-013 and T-021), Agencia Nacional de 
Ciencia y Tecnología and Chevron-Texaco, and grants to A.W.A.K from the Conselho Nacional de Desenvolvimento Científico e Tecnológico (CNPq, Project \#304785/2003-2) and Fundação Carlos Chagas Filho de Amparo à Pesquisa do Estado do Rio de Janeiro (FAPERJ, Project \# ${ }^{\circ}$ E-26/152.442/ 2002 - 2004).

\section{RESUMO}

O registro fóssil de elementos cranianos de titanossaurídeos é escasso, sendo que nenhum crânio completo foi descrito até o momento. Neste trabalho descrevemos um novo basicrânio (MUCPv-334) procedente de camadas avermelhadas do Subgrupo Rio Colorado (Cretáceo Superior) que afloram na região Bajo del Añelo, situada aproximadamente a $20 \mathrm{~km}$ norte da cidade Añelo (Província de Neuquén, Argentina). A presença de processos do basipterigoide direcionados ventralmente sugere que este exemplar represente um Titanosauridae. A robustez do basicrânio aliada à extensa crista proótica e a presença de uma prolongação do parasphenoide chegando até os basal tubera nunca tinham sido reportados em outros Titanosauridae, indicando que este clado de saurópodes possuía uma diversidade maior na morfologia do basicrânio do que se supunha.

Palavras-chave: basicrânio, Titanosauridae, Cretáceo Superior, Patagônia, Argentina.

\section{REFERENCES}

ARdolino AA AND FrAnCHI MR. 1996. Geología. In Geología y Recursos Minerales del Departamento Añelo. Cartas Geol y de Recursos Minerales de la prov Del Neuquén Bol 3: 9-150.

BERMAN DS AND JAIN SL. 1982. The braincase of a small sauropod dinosaur (Reptilia: Saurischia) from the Upper Cretaceous Lameta Group, Central India, with review of Lameta Group localities. Ann Carnegie Mus 51: 405-422.

CAlvo JO. 1994. Jaw mechanics in sauropod dinosaurs. In: Aspects of Sauropod Paleobiology. LOCKLEY MG, SAntos VF And MeYer CA (Eds). Gaia 10: 205-208.

Calvo JO and Kellner AWA. 2004. New titanosaurid braincase from the Rio Colorado Formation
(Late Cretaceous), Neuquén, Patagonia, Argentina. IV Simpósio Brasileiro de Paleontologia de Vertebrados, p. 9-10.

Calvo JO And Salgado L. 1995. Rebbachisaurus tessonei sp. nov., a new Sauropoda from the AlbainCenomanian of Argentina; New evidence on the origin of the Diplodocidae. Gaia 11: 13-33.

Calvo JO, Coria RA and Salgado L. 1997. Uno de los más completos titanosáuridos (DinosauriaSauropoda) registrados en el mundo. Ameghiniana 34: 534.

CAZAU LB AND UlianA MA. 1973. El Cretácico superior continental de la Cuenca Neuquina. V Congresso de Geologia Argentina, Villa Carlos Paz, Córdoba, Argentina. Actas 3: 131-163.

ChatTerJee S AND RudRA DK. 1996. KT events in India: impact, rifting, volcanism and dinosaur extinction. Mem Queensland Mus 39: 489-532.

Coombs WP. 1975. Sauropod habits and habitats. Palaeogeo, Palaeocli, Palaeoeco 17: 1-33.

CORIA RA AND SALGADo L. 1998. Nuevos aportes a la anatomía craneana de los saurópodos titanosáuridos. Ameghiniana 36: 98.

Currie PJ AND ZHaO XJ. 1994. A new troodontid (Dinosauria, Theropoda) braincase from the Dinosaur Park Formation (Campanian) of Alberta. Can J Earth Sci 30: 2231-2247.

Dodson P. 1990. Sauropod paleoecology. In: The Dinosauria. WeISHAMPEL DB, DODSON P AND Osmolska H (Eds), University of California Press, Berkeley, USA, p. 402-407.

GAuthIER JA. 1986. Saurischian monophyly and the origin of birds, In: The origin of birds and the evolution of flight. PADIAN K (Ed). Mem California Acad Sci 8: 1-55.

Henriques DDR, Kellner AWA, Azevedo SAK, SANTOS DE AND CRAIK MT. 2002. On a sauropod dinosaur (Titanosauridae) from the Adamantina Formation, Late Cretaceous. J Vert Paleont 22 (Suppl. 3): $64 \mathrm{~A}$.

Huene F von. 1929. Los Saurisquios y Ornitisquios del Cretácico Argentino. An Mus La Plata 3(2): 1-196.

Huene F von and Matley CA. 1933. The Cretaceous Saurischia and Ornithischia of the central province of India. Palaeont Indica 21: 1-74. 
Hunt AP, Lockley MG, LucAs SG AND MEyer CA. 1994. The global sauropod fossil record. Gaia 10: 261-279.

JACOBS LL, WINKLER DA, DOWNS WR AND GoMANI EM. 1993. New material of an early Cretaceous titanosaurid sauropod dinosaur from Malawi. Paleontology 36: 523-534.

JANENSCH W. 1929. Material und Formengehalt der Sauropoden in der Ausbeute der Tendaburu-Expedition. Palaeontographica Suppl 7 (2): 1-34.

KELLNER AWA. 1996. Description of the braincase of two Early Cretaceous pterosaurs (Pterodactyloidea) from Brazil. Am Mus Nov 3175: 1-34.

KurZanov SM AND BANNIKov AF. 1983. A new sauropod from the Upper Cretaceous of Mongolia. Paleontol Zhurnal 2: 90-96 (in Russian).

Le Loeuff J, Buffetaut E, Mechin P And MECHIN-SALESSY A. 1989. Un arrière-crâne de dinosaure titanosauridé (Saurischia, Sauropoda) dans le Crétacé supérieur du Var (Provence, France). Compt R Acad Scien Paris 309: 851-857.

LeAnZA HA AND Hugo CA. 2001. Cretaceous red beds from southern Neuquén Basin (Argentina): age, distribution and stratigraphic discontinuities. Asociación Paleontológica Argentina, Publicación Especial 7: 117-122.

MCInTOSH JS. 1990a. Sauropoda. In: WeISHAMPEL DB, Dodson P And Osmolska H (Eds), The Dinosauria, Univ Calif Press, Berkeley, p. 345-401.

MCINTOSH JS. 1990b. Species determination in sauropod dinosaurs with tentative suggestions for their classification. In: CARPENTER K AND CURRIE PJ (Eds), Dinosaur Systematic, Approaches and Perspectives, Cambridge University Press, p. 53-69.

MCInTOSH JS AND BeRman DS. 1975. Description of the palate and lower jaw of the sauropod dinosaur Diplodocus (Reptilia: Saurischia) with remarks on the nature of the skull of Aptosaurus. J Paleont 49: 187-199.

NowINSKI A. 1971. Nemegtosaurus mongoliensis n.gen., n.sp. (Sauropoda) from the uppermost Cretaceous of Mongolia. Paleont Polonica 25: 57-81.
Powell JE. 1992. Osteología de Saltasaurus loricatus (Sauropoda-Titanosauridae) del Cretácico Superior del noroeste argentino. In: Los Dinosaurios y su entorno biótico. SANZ JL AND BUSCALIONI AD (Eds), Instituto Juan de Valdés, Cuenca, España, p. 165-230.

Powell JE. 2003. Revision of South American Titanosaurid dinosaurs: palaeobiological, palaeobiogeographical and phylogenetic aspects. Records of the Queen Victoria Museum 111: 1-173.

Rogers KC AND Forster CA. 2001. The last of the dinosaur titans: a new sauropod from Madagascar. Nature 412: 530-534.

Rogers KC AND Forster CA. 2004. The skull of Rapetosaurus krausei (Sauropoda: Titanosauria) from the Late Cretaceous of Madagascar. J Vert Paleo 24: 121-144.

ROMER AS. 1956 Osteology of Reptiles. University of Chicago Press, Chicago, USA.

SALGADO L. 1999. The macroevolution of the Diplodocimorpha (Dinosauria; Sauropoda): a developmental model. Ameghiniana 36: 203-216.

SALGAdo L AND BonAPARTE JF. 1991. Un nuevo saurópodo Dicraeosauridae Amargasaurus cazaui gen. et sp.nov., de la Formacion La Amarga, Neocomiano de la provincia del Neuquén, Argentina. Ameghiniana 28: 333-346.

Salgado L AND CALVo JO. 1997. Evolution of titanosaurid sauropods. II: The cranial evidence. Ameghiniana 34: 33-47.

SAlgado L, Coria RA And CAlvo JO. 1997. Evolution of titanosaurid sauropods. I: Phylogenetic analysis based on the postcranial evidence. Ameghiniana 34: 3-32.

Tidwell V AND CARPenter K. 2003. Braincase of an early Cretaceous titanosauriform sauropod from Texas. J Vert Paleo 23: 176-180.

Weishampel DB, GRIGORESCU D AND NORMAN DB. 1991. Dinosaurs of Transylvania: Island biogeography in the Late Cretaceous. National Geographic Research and Exploration 7: 196-215. 